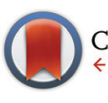

CrossMark click for updates

Cite this: Org. Biomol. Chem., 2015, 13, 9984

\section{Effects of multivalent histamine supported on gold nanoparticles: activation of histamine receptors by derivatized histamine at subnanomolar concentrations $\uparrow$}

\author{
Friederike Gasiorek, ${ }^{a}$ Ervice Pouokam, ${ }^{b}$ Martin Diener, ${ }^{\star b}$ Sabine Schlecht ${ }^{a}$ and \\ Mathias S. Wickleder*a
}

\begin{abstract}
Colloidal gold nanoparticles with a functionalized ligand shell were synthesized and used as new histamine receptor agonists. Mercaptoundecanoic acid moieties were attached to the surface of the nanoparticles and derivatized with native histamine. The multivalent presentation of the immobilized ligands carried by the gold nanoparticles resulted in extremely low activation concentrations for histamine receptors on rat colonic epithelium. As a functional read-out system, chloride secretion resulting from stimulation of neuronal and epithelial histamine $\mathrm{H}_{1}$ and $\mathrm{H}_{2}$ receptors was measured in Ussing chamber experiments. These responses were strictly attributed to the histamine entities as histamine-free particles Au-MUDOLS or the monovalent ligand AcS-MUDA-HA proved to be ineffective. The vitality of the tissues used was not impaired by the nanoparticles.
\end{abstract}

\author{
Received 3rd July 2015, \\ Accepted 5th August 2015 \\ DOI: 10.1039/c5ob01354b \\ www.rsc.org/obc
}

\section{Introduction}

During the past 20 years, the number of applications of nanoand microdevices in the fields of biotechnology and biomedicine has been increased drastically. ${ }^{1,2}$ Most promising tools are nanoparticles. ${ }^{3}$ They represent nanoscale materials with unique chemical and physical properties due to their size. These are for example optical absorption (metal nanoparticles), photoluminescence (semiconductor quantum dots) or magnetic behaviour (iron oxides). Their applicability derives not only from the fact that their dimension range is in the size of some biomolecules like proteins or receptors, but also that through simple surface modification a huge variety of interactions can be achieved. The basic requirement for every application is the proper surface functionalization of the particles, which determines their interaction with the environment. In this study we chose gold nanoparticles as a template because of their well-known synthesis and functionalization with small molecules. ${ }^{4,5}$ Moreover they are biocompatible. We took these

\footnotetext{
${ }^{a}$ Institute of Inorganic and Analytical Chemistry, Justus-Liebig-University, Heinrich-Buff-Ring 58, 35392 Giessen, Germany.

E-mail: friederike.gasiorek@anorg.chemie.uni-giessen.de

${ }^{b}$ Institute for Veterinary Physiology and Biochemistry, Justus-Liebig-University, Frankfurter Straße 100, 35392 Giessen, Germany.

E-mail: martin.diener@vetmed.uni-giessen.de

$\dagger$ Electronic supplementary information (ESI) available. See DOI: 10.1039/ c5ob01354b
}

particles and applied the concept of multivalency for the interaction with biological tissue. Multivalent presentation of immobilized ligands is a common concept in ligand-receptor interactions and can result in high affinities of ligands that possess only moderate binding constants in a similar concentration range when they are presented in their monovalent form. ${ }^{6-8}$ Simplifying binding structures reduces the synthetic complexity of the molecules immobilized on the nanoparticles and has the advantage of being synthetically well accessible. Multivalent carriers can either inhibit or activate biological processes in a different way than the monovalent analogue. Usually the effective concentration is much lower. ${ }^{9}$ There are only few examples where this concept is applied on receptorligand interactions with neurotransmitters. Paolino et al. synthesized dendrimeric tetravalent ligands for the activation of ligand-gated ion channels. ${ }^{10}$ Indeed they found activation concentrations in the low picomolar range. Saada et al. synthesized gold nanoparticles coated with histamine and applied the conjugates for enzyme activation. ${ }^{11}$ They also found an enhancement of the activation properties for these conjugates. Mediators such as histamine are key regulators of physiological processes such as ion transport across epithelial barriers. Chloride secretion is one of these processes occurring for example at the colonic epithelium. ${ }^{12,13}$ Such a secretion can be activated via stimulation of histamine $\mathrm{H}_{1}$ and/or $\mathrm{H}_{2}$ receptors as previously shown. ${ }^{14-16}$ The receptor activity can also be blocked by inhibitors, which are well-known for the histaminic receptors. Mediators or neurotransmitters represent an inter- 
esting class of bioactive molecules and yet there is no study on multivalent ligand presentation on biological systems. In this paper we report the immobilization and multivalence of the biogenic amine histamine on gold nanoparticles as well as its biological function in receptor activation.

\section{Results and discussion}

\section{Synthesis of the gold nanoparticles}

By attaching histamine derivatives on gold nanoparticles we developed a new conjugate for the interaction with compatible receptors. Water soluble gold nanoparticles with a terminally functionalized thiol shell were prepared and used as a scaffold for the multivalent presentation of histamine. Gold nanoparticles with an average diameter of $14 \mathrm{~nm}$ were synthesized by a modification of a well-known method developed by Turkevich et al. (Fig. 1). ${ }^{17,18}$

In an aqueous solution $\mathrm{Au}(\mathrm{III})$ was reduced by sodium citrate which serves not only as reducing agent but also as a ligand to prevent aggregation of the formed particles. Even if the solvent is limited to water or polar equivalents like DMSO, the resulting size of the particles can be defined by the molar ratios of the starting materials, the reaction temperature and time. By this method, gold nanoparticles with a diameter of $14 \mathrm{~nm}$ (NP 1, Fig. 1) could be obtained. Depending on the size of the particles, the surface is coated with several thousand ligands with respect to the steric demand of a single ligand. The resulting nanoparticles are stabilized by electrostatic repulsion of the negatively charged citrate ions adsorbed on their surface. This layer can be easily replaced by ligands with a stronger binding affinity, such as for example thiols. ${ }^{19,20}$ Thus, in a second step the ligand shell was substituted by a bivalent ligand. Bivalent ligands give access to further functionalization steps at the ligand periphery. One end binds to the surface and gives stability to the particle whereas the other end is exposed to the solution. Depending on the free moiety, the particles possess different stabilities at different $\mathrm{pH}$ values. There is a wide variety of ligands suitable for

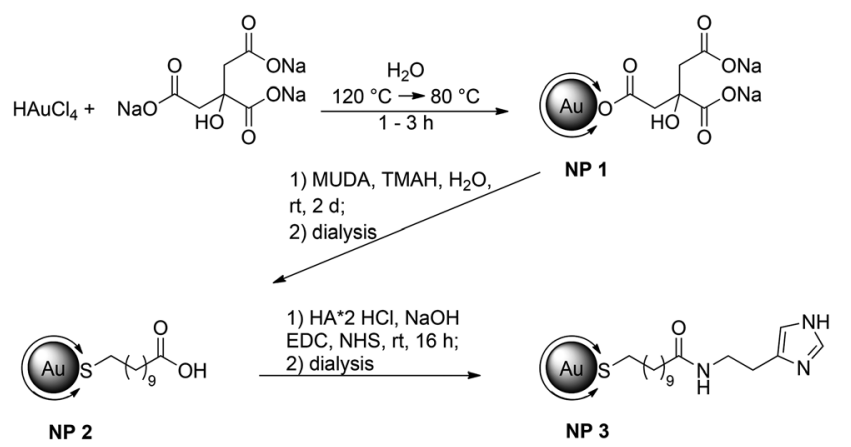

Fig. 1 Synthetic procedure for gold nanoparticles with a mean diameter of $14 \mathrm{~nm}$ (NP 1) followed by ligand exchange with 11-mercaptoundecanoic acid (NP 2) and functionalization with histamine (NP 3, AuMUDA-HA). Double arrows at the Au core represent the ligand. exchange still providing stability in aqueous media. Often poly (ethylene glycol) (PEG) is used as a ligand as it provides enough colloidal stability and reduces nonspecific adsorption. Besides "PEGylation", $\omega$-functionalized thiol surfactants with free carboxylic acid groups are a versatile type of ligand and are often used in aqueous solution. They offer an additional anchor point for further attachments of biological molecules. Herein we chose 11-mercaptoundecanoic acid (MUDA). On the one hand, a new bond between Au and S with high affinity is built upon transfer, ensuring a complete replacement of citrate due to strong binding affinities. On the other hand, the free carboxylic acid can serve as an anchor for further coupling reactions with amines. In addition, the long alkyl chain provides enough flexibility for the active moiety to interact multivalently with the receptor. The ligand exchange with MUDA giving NP 2 proceeded completely as it is indicated in the infra-red (IR) spectra (Fig. 2).

The final step towards the fully functionalized nanoparticle was accomplished by peptide coupling with EDC (1-ethyl-3-(3dimethylaminopropyl)carbodiimide) and NHS (N-hydroxy-succinimide). The free carboxylic acid is activated by EDC and forms with NHS in situ a so called 'active ester'. This reacts easier with amine moieties of e.g. amino acids or peptides. Although the prepared NHS ester is sufficiently stable for the reaction, it hydrolyses within hours depending on the $\mathrm{pH}$ of the reaction solution. To ensure the coupling, another equivalent of histamine, EDC and NHS were added after two hours. The excess of coupling agents and byproducts of the reaction were removed by purification with dialysis against water (MWCO 3500, three times). The characterization of the synthesized and functionalized nanoparticles NP 1-3 was per-

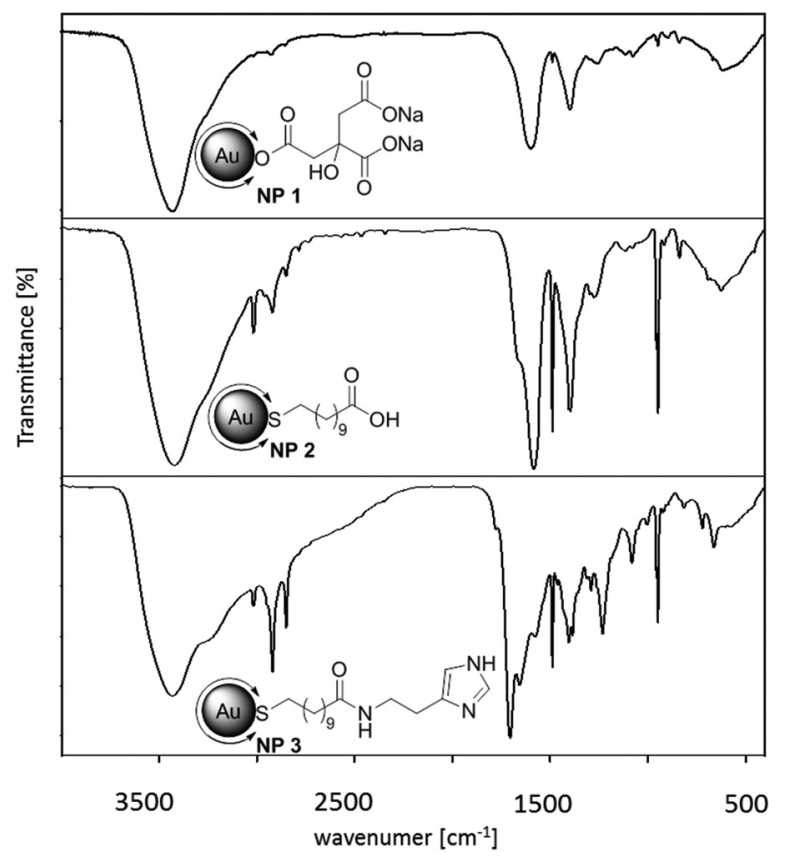

Fig. 2 IR spectra of (a) Au-Citrate NP 1, (b) Au-MUDA NP 2 and (c) AuMUDA-HA NP 3; vibration for the amide bond is found at $1641 \mathrm{~cm}^{-1}$. 


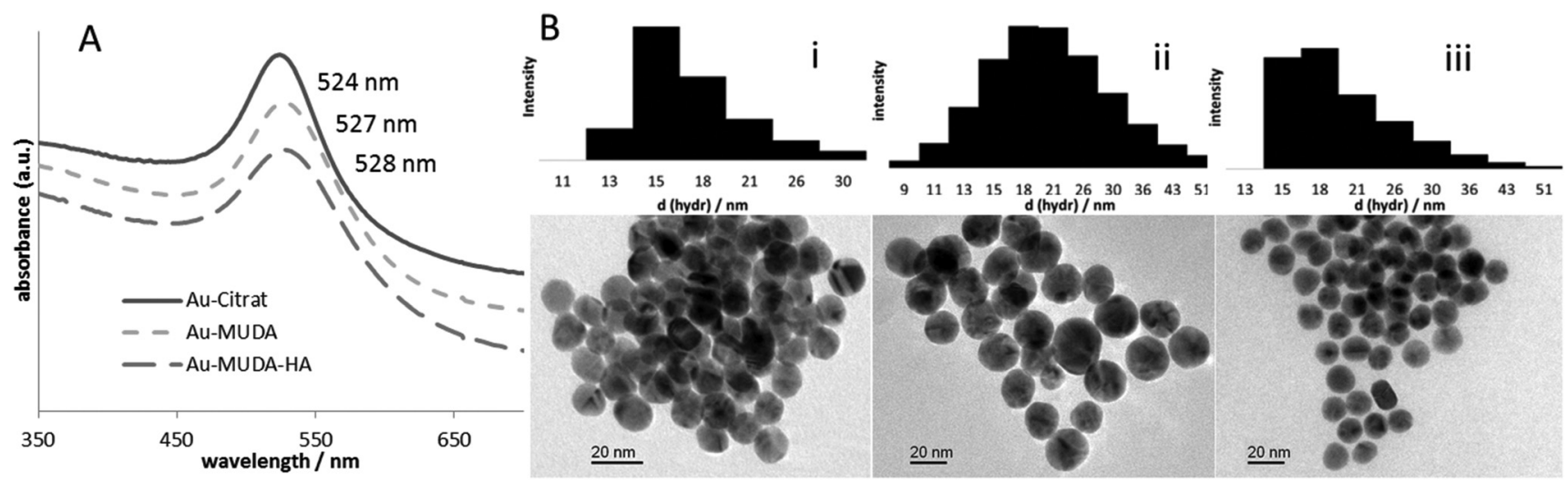

Fig. 3 (A) UV/Vis spectra of the stepwise functionalization of Au-Citrate NP 1, Au-MUDA NP 2 and Au-MUDA-HA NP 3 nanoparticles. (B) TEM images and DLS measurements with values for the distribution of the hydrodynamic diameters of (i) Au-Citrate NP $1 d=14.0 \pm 0.9 \mathrm{~nm}, d_{\mathrm{hydr}}=16.7$ $\pm 3.0 \mathrm{~nm}$, (ii) Au-MUDA NP $2 d=14.5 \pm 1.2 \mathrm{~nm}, d_{\mathrm{hydr}}=24.1 \pm 6.7 \mathrm{~nm}$ and (iii) Au-MUDA-HA NP $3 d=14.3 \pm 0.7 \mathrm{~nm}, d_{\mathrm{hydr}}=19.3 \pm 2.9 \mathrm{~nm} ; d=$ diameter.

formed with different methods. For the characterization of the core transmission electron microscope (TEM) images, dynamic light scattering (DLS) measurements and UV/Vis spectroscopy were used. The images shown in Fig. 3 indicate that the synthesized nanoparticles have mostly a spherical shape; the average diameter determined by TEM is $14.0 \pm 0.9 \mathrm{~nm}$. The hydrodynamic diameter of the nanoparticles in solution obtained by DLS measurements was determined by $16.7 \pm$ $3.0 \mathrm{~nm}$. The absorption maximum was found at $524 \mathrm{~nm}$. The position and form of the maximum is also a hint for the size of the nanoparticles, as it derives from a distinctive plasmon resonance at the gold surface depending on the shape of the material. The obtained data confirmed that the average diameter of the particles cores and the maxima of absorption remained unchanged after ligand exchange reaction and functionalization. The slight shift can be explained due to the new ligand. The affinity to a gold surface is higher for thiolated ligands than for citrate and therefore effects on the plasmon resonance of the particle. Nonetheless, neither the exchange of the ligands nor the purification via dialysis had an effect on the agglomeration state. Also the functionalization at the ligand periphery did not alter the particles significantly. In addition to these methods, the success of the ligand exchange was verified by IR spectroscopy (Fig. 2). Identification of the newly formed amide bond at $1641 \mathrm{~cm}^{-1}$ gives evidence for the successful coupling. Again the colloidal solution was purified by dialysis. Unlike the particles with MUDA as ligand shell, the final functionalization with histamine provides a good stability at physiological $\mathrm{pH}$ value and in a standard buffer solution for the Ussing chamber experiments (see below). The number of the ligands at the surface determined by TGA is about 10000 for $14 \mathrm{~nm}$ gold nanoparticles, however determination is difficult due to small amounts of product. In order to find out whether the size of the nanoparticles could be a limiting factor for their properties, two other sizes were investigated. Following the same synthetic procedure as described above but with different reaction conditions, $25 \mathrm{~nm}$ nanoparticles were obtained. Also, $7 \mathrm{~nm}$ nanoparticles were prepared using dodecanethiol-protected particles from the Stucky method as basic material. $^{21}$

As a negative control for the biochemical application, gold nanoparticles NP 4 (Fig. 4) with a sulfated ligand shell were

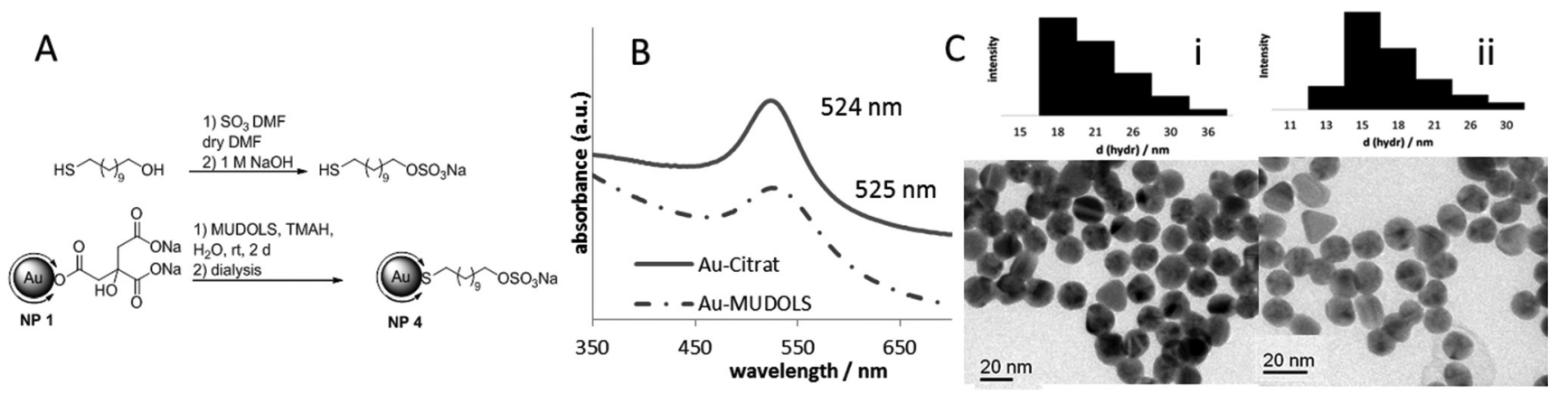

Fig. 4 (A) Synthetic procedure for the preparation of Au-MUDOLS NP 4, (B) UV/Vis spectra of Au-Citrate NP 1 and Au-MUDOLS NP 4, (C) TEM images and DLS measurements with values for the distribution of the hydrodynamic diameters of (i) Au-Citrate NP $1 d=14.0 \pm 0.9 \mathrm{~nm}, d_{\text {hydr }}=16.7$ $\pm 3.0 \mathrm{~nm}$, (ii) Au-MUDOLS NP $4 d=14.3 \pm 1.3 \mathrm{~nm}, d_{\mathrm{hydr}}=18.6 \pm 2.5 \mathrm{~nm} ; d=$ diameter. 
synthesized. We already reported from sulfated ligands for the inhibition of selectin binding. ${ }^{22}$ A structurally similar and simple ligand is sulfated 11-mercaptoundecanol (MUDOLS), which can be immobilized on gold nanoparticles in the same way as mentioned before. Again citrate-stabilized gold nanoparticles NP 1 served as basic material.

The sulfated ligand was synthesized separately and then attached to the surface via ligand exchange reaction. TEM images, DLS measurements and UV/Vis spectra (Fig. 4) indicated that the colloidal solution was intact and the nanoparticles were stable. Sulfated nanoparticles showed excellent stability over a wide range of $\mathrm{pH}$ value due to interparticle repulsion through a negatively charged ligand shell. Unlike the unsulfated Au-MUDA particles they are perfectly stable at physiological $\mathrm{pH}$.

When looking at multivalent effects, the monovalent ligand 3 (Fig. 5) also has to be investigated. Thus the complete ligand was synthesized separately. To prevent the formation of a disulfide bond between two molecules, the thiol moiety was protected with an acetyl group.

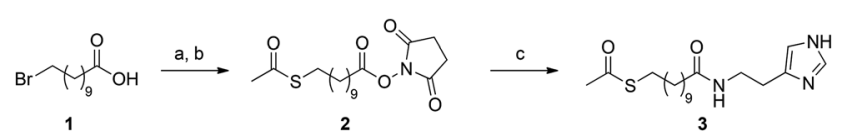

Fig. 5 Synthesis of the monovalent analogue AcS-MUDA-HA (3) starting from 11-bromoundecanoic acid 1. Reaction conditions: (a) KSOAc, DMF, 2 h, rt, (b) NHS, DCM, 18 h, rt, (c) EDC, HA.2HCl, NEt 3 , DCM, 6 h, rt.

\section{Functionality of the histamine-nanoparticles}

From all the synthesized nanoparticles of different sizes, only the $14 \mathrm{~nm}$ nanoparticles yielded consistent effects on shortcircuit current $\left(I_{\mathrm{sc}}\right)$ when they were administered to rat colonic mucosa mounted in Ussing chambers. Therefore, this type of particles was used for all subsequent experiments. To investigate the functionality of the Au-MUDA-HA nanoparticles, their ability to induce chloride secretion was compared with that of native histamine, which induces a strong chloride secretion across rat colonic epithelium. ${ }^{15,16}$ Indeed, the histamine-conjugated nanoparticles induced a concentrationdependent increase in $I_{\mathrm{sc}}$, which is a measure for net ion transport across the epithelium (Fig. 6).

These changes in $I_{\mathrm{sc}}$ reflect a secretion of chloride ions as they were abolished in $\mathrm{Cl}^{-}$-free buffer solution (Fig. 6). However, repetitive administration of these particles led to a desensitization of the tissue (Table 1). Thus in all subsequent experiments, each tissue was only exposed once to a single concentration of the Au-MUDA-HA nanoparticles $\left(10^{-11} \mathrm{~mol}\right.$ $\mathrm{I}^{-1}$ at the serosal side). The tissue conductance $\left(G_{\mathrm{t}}\right)$ was not significantly changed by the nanoparticles $\left(10^{-11} \mathrm{~mol} \mathrm{l}^{-1}\right.$ at the serosal side); $G_{\mathrm{t}}$ amounted to $14.4 \pm 1.87 \mathrm{mS} \mathrm{cm}^{-2}$ before and $14.7 \pm 1.96 \mathrm{mS} \mathrm{cm}^{-2}$ after administration of the particles ( $n=6$; difference not significant). Viability of the tissue was also not impaired by the Au-MUDA-HA nanoparticles as both the $\mathrm{Ca}^{2+}$-dependent secretagogue carbachol $\left(5 \times 10^{-5} \mathrm{~mol} \mathrm{l}^{-1}\right.$ at the serosal side), i.e. a stable derivative of acetylcholine, ${ }^{23}$ as well as the cAMP-dependent secretagogue forskolin $\left(5 \times 10^{-6}\right.$ mol $~^{-1}$ at the mucosal and the serosal side), which stimulates the intracellular production of $\mathrm{cAMP},{ }^{24}$ induced a prompt rise in $I_{\mathrm{sc}}$ in all tissues (Fig. 6). As the response to histamine evokes
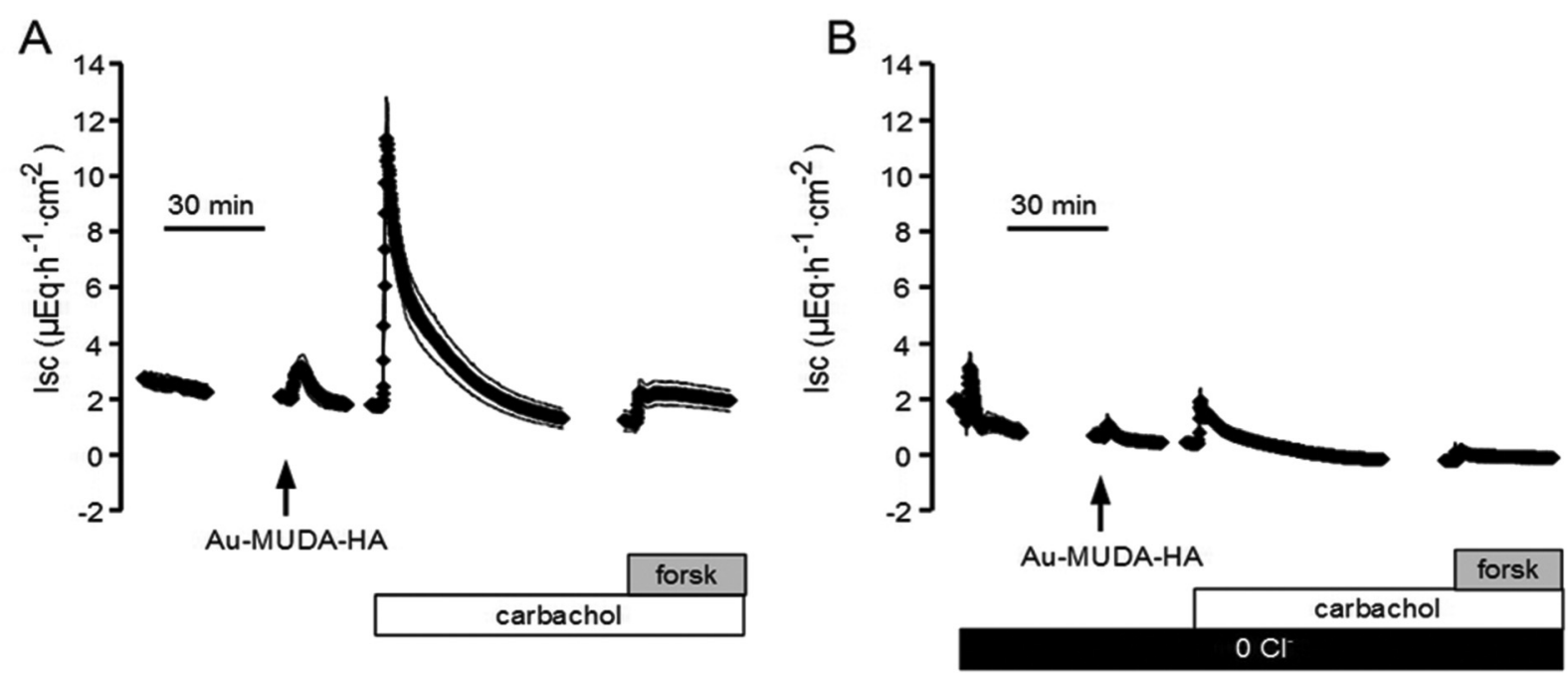

Fig. $6 \mathrm{Au}-\mathrm{MUDA}-\mathrm{HA}\left(10^{-11} \mathrm{~mol}^{-1}\right.$ at the serosal side, arrow) induced an increase in $I_{\mathrm{sc}}(\mathrm{A})$, which was almost abolished in the absence of chloride $\left(0 \mathrm{Cl}^{-}\right.$; black bar, (B). At the end of the experiments, the secretagogues carbachol $\left(5 \times 10^{-5} \mathrm{~mol} \mathrm{l}^{-1}\right.$ at the serosal side, white bars) and forskolin (forsk; $5 \times 10^{-6} \mathrm{~mol} \mathrm{l}^{-1}$ at the mucosal and the serosal side, grey bars, (A and B), known to induce chloride secretion, were administered. Line interruptions are caused by omission of time intervals in order to synchronize the tracings of individual records to the administration of drugs. Values are means (symbols) \pm SEM (parallel continuous lines), $n=6-8$. 
Table 1 Effects of additive concentrations of Au-MUDA-HA $14 \mathrm{~nm}$ on $I_{\mathrm{sc}}$ and $\mathrm{H}_{1}$ and $\mathrm{H}_{2}$ receptors

Increase in short-circuit current $\Delta I_{\mathrm{sc}}$ $\left(\mu \mathrm{Eq} \mathrm{h}{ }^{-1} \mathrm{~cm}^{-2}\right)$

\section{$\mathrm{Au}-\mathrm{MUDA}-\mathrm{HA} 14 \mathrm{~nm}$}

\begin{tabular}{llll}
\hline $\begin{array}{l}\text { No inhibitor } \\
\text { Mepyramine }+\end{array}$ & $1.09 \pm 0.43^{\mathrm{b}}$ & $0.61 \pm 0.11^{\mathrm{a}, \mathrm{b}}$ & $0.42 \pm 0.11^{\mathrm{a}, \mathrm{b}}$ \\
cimetidine & $0.083 \pm 0.041^{\mathrm{a}}$ & $0.13 \pm 0.033^{\mathrm{a}}$ & $0.13 \pm 0.02^{\mathrm{a}}$
\end{tabular}

Cumulative administration of gradually increased concentrations $\left(10^{-11}, 5 \times 10^{-11}, 10^{-10} \mathrm{~mol} \mathrm{l}^{-1}\right.$, at the serosal side $)$ of Au-MUDA-HA induced an increase in $I_{\mathrm{sc}}$ concomitant with an obvious desensitization of the tissue as indicated by the reduced $I_{\mathrm{sc}}$ response after repeated administration. Given is the control response in the absence of any inhibitors and the response to Au-MUDA-HA in the combined presence of mepyramine $\left(10^{-4} \mathrm{~mol} \mathrm{l}^{-1}\right.$ at the serosal side $)$ and cimetidine $\left(10^{-4} \mathrm{~mol} \mathrm{l}^{-1}\right.$ at the serosal side). Values are given as difference to the baseline in $I_{\mathrm{sc}}$ just before administration of the corresponding agonist $\left(\Delta I_{\mathrm{sc}}\right)$ and are means $\pm \mathrm{SEM}, n=6$. Different letters $(\mathrm{a}, \mathrm{b}, \mathrm{c})$ indicate statistically homogenous groups (analysis of variances followed by post hoc test of Tukey).

chloride secretion in part via stimulation of histamine receptors located on submucosal neurons, the effect of the inhibitory neurotoxin tetrodotoxin, which inhibits the propagation of action potentials via blockade of voltage-dependent $\mathrm{Na}^{+}$ channels, on the $I_{\mathrm{sc}}$ evoked by the Au-MUDA-HA nanoparticles was investigated. ${ }^{16,25}$ Ideed, in the presence of tetrodotoxin $\left(10^{-6} \mathrm{~mol} \mathrm{l}^{-1}\right.$ at the serosal side), the $I_{\mathrm{sc}}$ evoked by $\mathrm{Au}-$ MUDA-HA $\left(10^{-11} \mathrm{~mol} \mathrm{l}^{-1}\right.$ at the serosal side $)$ only amounted to $0.69 \pm 0.20 \mu \mathrm{Eq} \mathrm{h}^{-1} \mathrm{~cm}^{-2}(n=6)$ in comparison to $2.92 \pm 0.64$ $\mu \mathrm{Eq} \mathrm{h} \mathrm{h}^{-1} \mathrm{~cm}^{-2}$ in untreated control tissues $(P<0.05, n=6)$.

The response to native histamine is mediated by stimulation of histamine $\mathrm{H}_{1}$ and histamine $\mathrm{H}_{2}$ receptors. $^{16}$ In accordance with that observation, the increase in $I_{\mathrm{sc}}$ evoked by $\mathrm{Au}-\mathrm{MUDA}-\mathrm{HA}\left(10^{-11} \mathrm{~mol} \mathrm{l}^{-1}\right.$ at the serosal side) was strongly inhibited by a combination of the histamine $\mathrm{H}_{1}$ receptor blocker, mepyramine $\left(10^{-4} \mathrm{~mol} \mathrm{l}^{-1}\right.$ at the serosal side $)$, and the histamine $\mathrm{H}_{2}$ receptor blocker, cimetidine $\left(10^{-4}\right.$ mol $\mathrm{l}^{-1}$ at the serosal side, Table 1). Mepyramine is a substituted ethylamine derivative, whereas cimetidine has an imidazole ring system similar to native histamine. ${ }^{26}$ Both drugs act as competitive inhibitors of the G-protein coupled histamine receptors type $1^{26}$ and type $2,{ }^{27}$ respectively.

Viability of the tissue was not altered, as forskolin, the activator of adenylate cyclase(s), ${ }^{24}$ evoked an increase in $I_{\mathrm{sc}}$ of $11.90 \pm 1.10 \mu \mathrm{Eq} \mathrm{h}^{-1} \mathrm{~cm}^{-2}(n=6)$ in the absence and of 10.72 $\pm 1.18 \mu \mathrm{Eq} \mathrm{h} \mathrm{h}^{-1} \mathrm{~cm}^{-2}$ ( $n=6$, difference not significant) in the presence of the histamine receptors antagonists.

\section{Controls with histamine-free nanoparticles}

In order to make sure that the effects of the nanoparticles are not unspecific artefacts resulting from the assembly components of the particles, controls were performed either with the conjugator AcS-MUDA-HA or with the sulfated moiety AuMUDOLS. As shown in Fig. 7, these components failed to induce a rise in $I_{\mathrm{sc}}$. Furthermore, Au-MUDOLS impaired the viability of the epithelium as it prevented the secretion induced by a subsequent administration of forskolin $\left(5 \times 10^{-6}\right.$ mol $\mathrm{l}^{-1}$ at the mucosal and the serosal side).

\section{Potency of the Au-MUDA-HA nanoparticles}

The highest changes in the $I_{\mathrm{sc}}$ or the $G_{\mathrm{t}}$ induced by the nanoparticles were obtained at the concentration $10^{-11} \mathrm{~mol} \mathrm{l}^{-1}$. For the $I_{\mathrm{sc}}$, the change amounted to $1.09 \pm 0.42 \mu \mathrm{Eq} \mathrm{h} \mathrm{h}^{-1} \mathrm{~cm}^{-2}$. When comparing this response with a concentration-response curve of native histamine (Fig. 8) it turned out that a comparable increase in $I_{\mathrm{sc}}\left(1.05 \pm 0.24 \mu \mathrm{Eq} \mathrm{h} \mathrm{h}^{-1} \mathrm{~cm}^{-2}\right)$ was obtained with histamine in a concentration of $10^{-5}$ mol $\mathrm{l}^{-1}$ (Fig. 8B). Assuming a maximum of 10000 histaminic units at the surface determined by TGA, the relative potency is still some magnitudes higher. In other words, the conjugation to the $14 \mathrm{~nm}$ nanoparticles strongly enhanced the potency of histamine to evoke anion secretion.
A

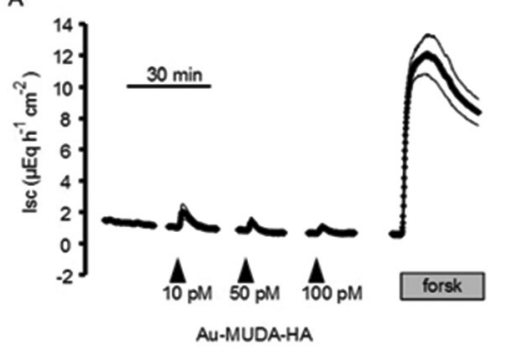

B

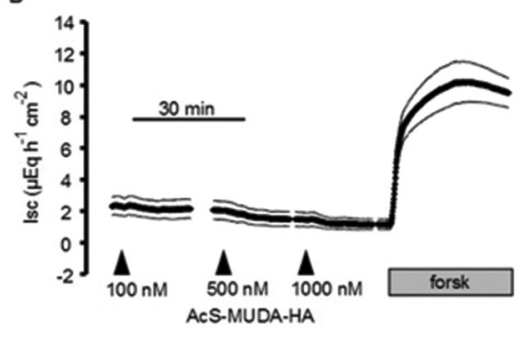

C

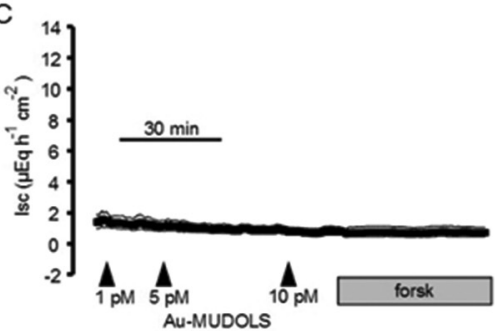

Fig. 7 Au-MUDA-HA $\left(10^{-11}, 5 \times 10^{-11}, 10^{-10} \mathrm{~mol} \mathrm{l}^{-1}\right.$, administered cumulatively at the serosal side, arrows) induced an increase in $I_{\mathrm{sc}}$. (B) AcSMUDA-HA $\left(10^{-7}, 5 \times 10^{-7}, 10^{-6} \mathrm{~mol} \mathrm{l}^{-1}\right.$, at the serosal side, arrows) was ineffective. (C) Au-MUDOLS $\left(10^{-12}, 5 \times 10^{-12}, 10^{-11} \mathrm{~mol} \mathrm{l}^{-1}\right.$, at the serosal side, arrows) failed to change the $I_{\mathrm{sc}}$. All particles except Au-MUDOLS preserved the secretory function of the tissues as they did not impair the effect of the secretagogue forskolin (forsk; $5 \times 10^{-6} \mathrm{~mol} \mathrm{l}^{-1}$ at the mucosal and the serosal side, grey bars). Values are means (symbols) \pm SEM (parallel continuous lines), $n=4-8$. 
A
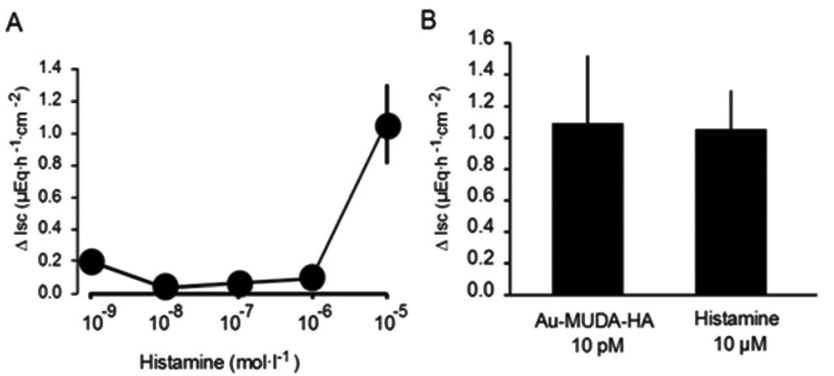

Fig. 8 (A) Histamine induced a concentration-dependent increase in $I_{\mathrm{sc}}$. (B) Shows the potency of Au-MUDA-HA versus histamine; an equivalent potency between $\mathrm{Au}-\mathrm{MUDA}-\mathrm{HA}$ and histamine was obtained with $10^{-11} \mathrm{~mol} \mathrm{l}^{-1}$ and $10^{-5} \mathrm{~mol} \mathrm{l}^{-1}$, respectively. Values are given as increase in $I_{\mathrm{sc}}$ above baseline in short-circuit current $\left(\Delta I_{\mathrm{sc}}\right)$ just before administration of the corresponding drug and are means $\pm \mathrm{SEM}, n=$ $6-8$.

\section{Conclusion}

The gold nanoparticles with an average diameter of $14 \mathrm{~nm}$ were loaded with the histamine derivative and showed excellent activation properties in the Ussing chamber experiments. Compared to native histamine, the nanoparticles were more effective at extremely low concentrations. It was found that the newly developed conjugate was able to induce a concentrationdependent chloride secretion across rat colonic epithelium via stimulation of histamine $\mathrm{H}_{1}$ and $\mathrm{H}_{2}$ receptors. These receptors, which are composed of 487 or 359 amino acids, respectively, belong to the class of G-protein coupled receptors with seven transmembrane spanning regions. Upon binding of the agonist, these receptors induce the exchange of guanosine diphosphate (GDP) against guanosine triphosphate (GTP) at the a-subunit of trimeric GTP-binding proteins. The consequence is the dissociation of the G-protein in the GTP-binding a-subunit and a b/g-complex and the activation of intracellular enzymes such as phospholipase $\mathrm{C}$ or adenylate cyclase, which then activate intracellular second messenger pathways. ${ }^{28}$ An explanation for this stimulation might be the high local density of the immobilized ligand. The molecular recognition between the receptors on the surface and ligands bound to the nanoparticles is strengthened through the geometric arrangement given by the spherical shape. The density of the binding moieties allows simultaneous binding resulting in a lower activation concentration. ${ }^{29}$ The interaction can be blocked with same inhibitors used for native histamine. To ensure the response originated only from multivalent histamine supported on gold nanoparticles and not from any unspecific interactions with the biological tissue, the monovalent ligand AcS-MUDA-HA or the gold nanoparticles with a simple sulfated moiety from 11-mercaptoundecanol were synthesized and tested in parallel. Indeed, no chloride secretion could be observed. All particles tested in this study preserved the basic functions of the tissues except for Au-MUDOLS. Only the particles with the sulfated moiety harmed the tissues irreversibly.
Among the three sizes of particles tested $(7 \mathrm{~nm}, 14 \mathrm{~nm}$ and $25 \mathrm{~nm}$ ), only the intermediate size $14 \mathrm{~nm}$ showed consistent effects on transepithelial $\mathrm{Cl}^{-}$secretion, indicating a sizedependence. The smaller nanoparticles exhibited unspecific interactions whereas the bigger particles evoked no signal in the Ussing chamber experiments. The observed size dependence might correlate with the number of histamine molecules at the surface. The density of immobilized histamine moieties at $14 \mathrm{~nm}$ core size and the spatial arrangement are both essential for the activation of histaminic receptors bound on an epithelium. For a detailed insight into the mechanisms of receptor activation further experiments will be conducted on the ligand-receptor-complex which is formed during the activation process. But also the length of the spacer between the particle core and the active moiety influences the interplay, as it was shown in one of our previous studies on multivalent interactions of gold nanoparticles in selectin binding. ${ }^{22}$ Further investigations shall be conducted on this influence. In summary the present work is another example for the influence of multivalent interactions in biological systems. This concept can also be transferred to other receptor antagonists and to different neurotransmitters.

\section{Experimental section}

All reactions of nanoparticles in aqueous solution were carried out in purified Millipore water. Organic solvents were distilled before use. All chemicals were purchased from commercial sources and used as received. The ligand exchange reactions and coupling reactions were done under inert conditions. All glass vessels were washed with aqua regia and distilled water prior to use. NMR spectra were recorded on Bruker BioSpin Avance III AV600 (600 MHz), AV400 (400 MHz) or AV200 (200 MHz) spectrometers using tetramethylsilane (TMS) as an internal standard with chemical shifts given in ppm relative to TMS $(\delta=0.00 \mathrm{ppm})$ or the respective solvent peaks. ${ }^{1} \mathrm{H}$ NMR data are reported as follows: chemical shifts (multiplicity [ppm], coupling constants $[\mathrm{Hz}]$, integration, classification). Multiplicity is recorded as $\mathrm{s}=$ singlet, br $\mathrm{s}=$ broadened singlet, $\mathrm{d}=$ doublet, $\mathrm{t}=$ triplet, $\mathrm{q}=$ quartet, $\mathrm{m}=$ multiplet. For ${ }^{13} \mathrm{C}$ NMR, chemical shifts and structural assignments are reported where applicable. Because of the rigidity of the alkyl chains in the thiol shells and the resulting large differences in the relaxation times of different protons, no integrals are given for the proton NMR data of the gold colloids. IR spectra were obtained on a Bruker IFS48 spectrometer in ATR mode. Electrospray ionization mass spectra (ESI-MS) were recorded on a Finnigan LCQDuo spectrometer using methanol solutions of the respective. TEM measurements were performed on a Philips CM30 STEM (300 kV, LaB6-cathode) equipped with a GATAN digital camera. TEM images were recorded using a digital micrograph. The average particle core sizes were determined by measuring at least 100 individual particles from recorded TEM images. The UV/Vis spectra were plotted with an Agilent 8453 spectrophotometer (Agilent Technologies Inc., Santa 
Clara, CA, USA). Dynamic light scattering measurements were performed with a StabiSizer PMX 200C from Particlemetrix (Meerbusch, Germany).

\section{Chemical syntheses}

Citrate-coordinated gold nanoparticles NP 1 (Au-Citrate $\varnothing$ 14 nm). Citrate-coordinated gold nanoparticles were synthesized by a variation of a procedure first published by Turkevich. A solution of $50 \mathrm{mg}(0.127 \mathrm{mmol}) \mathrm{HAuCl}_{4} \cdot 3 \mathrm{H}_{2} \mathrm{O}$ in $195 \mathrm{~mL}$ of Millipore water was heated to reflux for $20 \mathrm{~min}$. Under vigorous stirring a solution of $224 \mathrm{mg}(0.52 \mathrm{mmol})$ of sodium citrate in $5 \mathrm{~mL}$ of Millipore water was added quickly. The reaction mixture was held at $80{ }^{\circ} \mathrm{C}$ for $2 \mathrm{~h}$. Then the solution was cooled to $0^{\circ} \mathrm{C}$ in an ice bath and filtered $(0.2 \mu \mathrm{m}$ pore size). A clear red solution with a particle concentration of $2.7 \mathrm{nM}$ was obtained and stored at $4{ }^{\circ} \mathrm{C}$.

${ }^{1} \mathrm{H}$ NMR $\left(400 \mathrm{MHz}, \mathrm{D}_{2} \mathrm{O}\right): \delta / \mathrm{ppm}=2.61\left(\mathrm{bs}, \mathrm{CH}_{2}\right) ; \mathrm{IR}(\mathrm{KBr}$ disc, $\left.\nu / \mathrm{cm}^{-1}\right)$ : $3426.8(\nu \mathrm{O}-\mathrm{H}), 1598.2(\nu \mathrm{C}=\mathrm{O}), 1397.6,1258.4$, 618.0; TEM: $d=14.0 \pm 0.9 \mathrm{~nm}$; UV/Vis: $\lambda_{\max }=522 \mathrm{~nm}$; DLS: $d_{\text {hydr }}=16.7 \pm 3.0 \mathrm{~nm}$.

11-Mercaptoundecanoic acid coordinated gold nanoparticles NP 2 (Au-MUDA Ø 14 nm). An amount of $21 \mathrm{mg}$ 11-mercaptoundecanoic acid (0.1 mmol, $10^{5}$ equiv.) was dissolved in $8.5 \mathrm{~mL}$ Millipore water under the addition of $50 \mu \mathrm{L}$ tetramethylammonium hydroxide (TMAH). $5 \mathrm{~mL}$ of a $2.7 \mathrm{nM}$ solution of citrate-protected gold nanoparticles in water was added dropwise and the solution was stirred for $24 \mathrm{~h}$. The nanoparticles solution was dialysed against $300 \mathrm{~mL}$ water three times (3500 MWCO). A clear red solution with a particle concentration of $1 \mathrm{nM}$ was obtained and stored at $4{ }^{\circ} \mathrm{C}$.

${ }^{1} \mathrm{H}$ NMR (400 MHz, D $\left.\mathrm{O}\right): 3.17$ (s, 16H, TMAH), $2.76(\mathrm{t}$, $\mathrm{CH}_{2}$ ), 2.16 (t, $\mathrm{CH}_{2}$ ), 1.73 (quin, $\mathrm{CH}_{2}$ ), $1.54\left(\mathrm{~m}, \mathrm{CH}_{2}\right), 1.40(\mathrm{~m}$, $\mathrm{CH}_{2}$ ), 1.30 (bs, $\mathrm{CH}_{2}$ ); IR ( $\mathrm{KBr}$ disc, $\nu / \mathrm{cm}^{-1}$ ): 3422.8, 3018.5, $2920.1 \& 2849.8(\nu \mathrm{C}-\mathrm{H}), 1583.5(\nu \mathrm{C}=\mathrm{O}), 1487.9,1396.2$, 1274.9, 956.8, 948.2, 625.0; TEM: $d=14.5 \pm 1.2 \mathrm{~nm}$, UV/Vis: $\lambda_{\max }=527 \mathrm{~nm}$, DLS: $d_{\text {hydr }}=24.1 \pm 6.7 \mathrm{~nm}$.

Sodium 11-mercaptoundecyl sulfate coordinated gold nanoparticles NP 4 (Au-MUDOLS $\varnothing 14 \mathbf{n m})$. An amount of $30 \mathrm{mg}$ 11-mercaptoundecanyl sulfate was dissolved in $8.5 \mathrm{~mL}$ Millipore water and $50 \mu \mathrm{L}$ tetramethylammonium hydroxide (TMAH) was added. $5 \mathrm{~mL}$ of a $2.7 \mathrm{nM}$ solution of citrate-protected gold nanoparticles in water was added dropwise and the solution was stirred for $24 \mathrm{~h}$. The nanoparticles solution was dialysed against $300 \mathrm{~mL}$ water three times (3500 MWCO) and stored at $4{ }^{\circ} \mathrm{C}$.

${ }^{1} \mathrm{H}$ NMR $\left(400 \mathrm{MHz}, \mathrm{D}_{2} \mathrm{O}\right): \delta / \mathrm{ppm}=4.00-3.89\left(\mathrm{~m}, \mathrm{CH}_{2}\right)$, 2.70-2.60 (m, $\left.\mathrm{CH}_{2}\right), 1.68-1.51\left(\mathrm{~m}, \mathrm{CH}_{2}\right), 1.37-1.23\left(\mathrm{~m}, \mathrm{CH}_{2}\right)$; IR ( $\mathrm{KBr}$ disc, $\left.\nu / \mathrm{cm}^{-1}\right): 2918.7 \& 2849.9(\nu \mathrm{C}-\mathrm{H}), 1614.8,1470.0$, $1261.7 \& 1205.1 \& 1128.1\left(\nu\left(\mathrm{R}-\mathrm{OSO}_{2}-\mathrm{OR}\right), 1068.8,966.4,831.8\right.$, 718.9, 628.7, 586.3; TEM: $d=14.3 \pm 1.3 \mathrm{~nm}$; UV/Vis: $\lambda_{\max }=$ $525 \mathrm{~nm}$; DLS: $d_{\mathrm{hydr}}=18.6 \pm 2.5 \mathrm{~nm}$.

Synthesis of histamine functionalized gold nanoparticles NP 3 (Au-MUDA-HA $\varnothing 14 \mathbf{~ n m}$ ). $10 \mathrm{~mL}$ of a $1 \mathrm{nM}$ solution $\mathrm{Au}-$ MUDA were set in a glass vessel washed with aqua regia and distilled water. $18 \mathrm{mg}$ histamine dihydrochloride $(0.1 \mathrm{mmol})$, $17 \mathrm{mg}$ EDC (0.11 mmol) and $15 \mathrm{mg}$ HOBt $(0.11 \mathrm{mmol})$ and 50 $\mu \mathrm{LEt}_{3}$ were added to the nanoparticle solution. The reaction mixture was stirred overnight and subsequently dialysed against water three times (3500 MWCO) and stored at $4{ }^{\circ} \mathrm{C}$.

${ }^{1} \mathrm{H}$ NMR (400 MHz, $\left.\mathrm{D}_{2} \mathrm{O}\right): 7.55(\mathrm{~s}, 1 \mathrm{H}, \mathrm{CH}), 6.81(\mathrm{~s}, 1 \mathrm{H}, \mathrm{CH})$, 2.73-2.86 (m, 2H, $\left.\mathrm{CH}_{2}(\mathrm{HA})\right), 2.57-2.71\left(\mathrm{~m}, 3 \mathrm{H}, \mathrm{CH}_{2}(\mathrm{HA})+\right.$ $\mathrm{NH})$ ), 2.41-2.53 (m, 2H), 2.21-2.34 (m, 4H), 2.10-2.21 (m, 3H), $2.03(\mathrm{t}, J=7.7,1 \mathrm{H}), 1.52-1.68(\mathrm{~m}, 1 \mathrm{H}), 1.36-1.48(\mathrm{~m}, 1 \mathrm{H}), 1.18$ (bs, $8 \mathrm{H}, \mathrm{CH}_{2}$ ), IR ( $\mathrm{KBr}$ disc, $\nu / \mathrm{cm}^{-1}$ ): 3018.8, $2921.4 \& 2850.0$ $(\nu \mathrm{C}-\mathrm{H}), 1641.1(\nu \mathrm{C}=\mathrm{O}$, amide), 1596.3 ( $\nu \mathrm{CO}-\mathrm{NH})$, 1488.2, 1404.2, 957.1, 948.6, TEM: $d=14.3 \pm 0.7 \mathrm{~nm}$, UV/Vis: $\lambda_{\max }=$ $528 \mathrm{~nm}$, DLS: $d_{\text {hydr }}=19.3 \pm 2.9 \mathrm{~nm}$.

Sodium 11-mercaptoundecyl sulfate (MUDOLS). In a flamedried vessel under argon atmosphere, $353 \mathrm{mg}$ of 11-mercaptoundecanol (1.72 mmol, 1 equiv.) was dissolved in $3 \mathrm{ml}$ dry DMF. Separately, $395 \mathrm{mg}$ of $\mathrm{SO}_{3} \cdot \mathrm{DMF}$ complex $(2.5 \mathrm{mmol}$, 1.5 equiv.) were dissolved in $1 \mathrm{~mL}$ dry DMF and added to the solution. After stirring for $1 \mathrm{~h}$ at room temperature the solvent was removed under reduced pressure (OPV) and the residue was dissolved in $4 \mathrm{~mL}$ of $1 \mathrm{M} \mathrm{NaOH}$. A white precipitate appeared. $15 \mathrm{~mL}$ of ethanol were added and washed three times. The product was dried in vacuum. $280 \mathrm{mg}$ of a colorless solid (0.91 mmol, 53\%) could be obtained. The dimer was formed.

${ }^{1} \mathrm{H}$ NMR $\left(200 \mathrm{MHz}, \mathrm{DMSO}-\mathrm{d}_{6}\right): \delta / \mathrm{ppm}=3.68(\mathrm{t}, J=6.6 \mathrm{~Hz}$, $2 \mathrm{H}, \mathrm{CH}_{2}$ ), $3.35\left(\mathrm{t}, J=6.3 \mathrm{~Hz}, 2 \mathrm{H}, \mathrm{CH}_{2}\right), 2.27-2.61(\mathrm{~m}, 4 \mathrm{H}$, $\left.\mathrm{CH}_{2}\right)$, 2.56-2.49 (m, 2H, $\left.\mathrm{CH}_{2}\right), 1.67-1.52\left(\mathrm{~m}, 4 \mathrm{H}, \mathrm{CH}_{2}\right)$, 1.36-1.24 (m, 10H, $\left.\mathrm{CH}_{2}\right) ;{ }^{13} \mathrm{C}$ NMR (200 MHz, DMSO-d 6 ): $\delta / \mathrm{ppm}=65.6,60.7,32.5,29.1,29.0,28.9,28.8,28.6,28.5,27.7$, 25.5; ESI-MS: $m / z=633.1593\left([\mathrm{M}+\mathrm{Na}]^{+}\right.$, calcd 633.1612).

11-(Acetylthio)undecanoic acid (AcS-MUDA). 500 mg 11bromoundecanoic acid (1.89 mmol, 1 equiv.) were dissolved in $70 \mathrm{~mL}$ absolute DMF under argon atmosphere. Separately $520 \mathrm{mg}$ potassium thioacetate (4.56 mmol, 2.4 equiv.) were suspended in $8 \mathrm{~mL}$ absolute DMF under argon atmosphere and added dropwise to the first solution. The reaction mixture was stirred for 2 hours at room temperature. The precipitate was filtered off, washed several times with water and dried in vacuum. $414 \mathrm{mg}$ of a colorless solid (1.59 mmol, 84\%) could be obtained.

${ }^{1} \mathrm{H} \mathrm{NMR}\left(200 \mathrm{MHz}, \mathrm{CDCl}_{3}\right): \delta / \mathrm{ppm}=2.79(\mathrm{t}, J=7.17,2 \mathrm{H}$, $\left.\mathrm{CH}_{2}\right), 2.27\left(\mathrm{t}, J=7.17,2 \mathrm{H}, \mathrm{CH}_{2}\right), 2.25\left(\mathrm{~s}, 3 \mathrm{H}, \mathrm{CH}_{3}\right), 1.61-1.52$ $\left(\mathrm{m}, 2 \mathrm{H}, \mathrm{CH}_{2}\right), 1.52-1.44\left(\mathrm{~m}, 2 \mathrm{H}, \mathrm{CH}_{2}\right), 1.32-1.16(\mathrm{~m}, 12 \mathrm{H}$, $\left.\mathrm{CH}_{2}\right) ;{ }^{13} \mathrm{C}$ NMR $\left(100 \mathrm{MHz}, \mathrm{CDCl}_{3}\right): \delta / \mathrm{ppm}=196.2\left(\mathrm{C}_{\mathrm{q}}, \mathrm{C}=\mathrm{O}\right.$, acetyl), 179.4, 33.9, 30.7, 29.5, 29.4, 29.3, 29.2, 29.1, 29.1, 29.0, 28.8, 24.7; ESI-MS: $m / z=283.1335\left([\mathrm{M}+\mathrm{Na}]^{+}\right.$, calcd 283.1344).

2,5-Dioxopyrrolidin-1-yl-11-(acetylthio-)undecanoate (AcSMUDA-NHS). $195 \mathrm{mg}$ NHS (1.7 mmol, 1.1 equiv.) and $700 \mathrm{mg}$ AcS-MUDA (1.55 mmol, 1 equiv.) were dissolved in DCM under stirring at room temperature. $350 \mathrm{mg}$ DCC $(1.7 \mathrm{mmol}$, 1.1 equiv.) were separately dissolved in $5 \mathrm{~mL}$ DCM and added slowly. After $30 \mathrm{~min}$ a white precipitate appeared. The reaction mixture was stirred overnight. The solvent was removed under reduced pressure. $506 \mathrm{mg}$ (1.42 $\mathrm{mmol}, 92 \%)$ of a colorless powder were obtained.

${ }^{1} \mathrm{H}$ NMR $\left(400 \mathrm{MHz}, \mathrm{CDCl}_{3}\right): \delta / \mathrm{ppm}=2.81-2.77\left(\mathrm{~m}, \mathrm{CH}_{2}\right)$, $2.53\left(\mathrm{t}, J=7.34,2 \mathrm{H}, \mathrm{CH}_{2}\right), 2.25\left(\mathrm{~s}, 3 \mathrm{H}, \mathrm{CH}_{3}\right), 1.71-1.63(\mathrm{~m}, 2 \mathrm{H}$, $\left.\mathrm{CH}_{2}\right), 1.52-1.47\left(\mathrm{~m}, 2 \mathrm{H}, \mathrm{CH}_{2}\right), 1.38-1.17\left(\mathrm{~m}, 12 \mathrm{H}, \mathrm{CH}_{2}\right) ;{ }^{13} \mathrm{C}$ 
NMR (100 MHz, $\left.\mathrm{CDCl}_{3}\right): \delta / \mathrm{ppm}=196.1\left(\mathrm{C}_{\mathrm{q}}, \mathrm{C}=\mathrm{O}\right.$, acetyl), $169.3\left(2 \times \mathrm{C}_{\mathrm{q}}, \mathrm{C}=\mathrm{O}\right), 168.7\left(\mathrm{C}_{\mathrm{q}}, \mathrm{C}=\mathrm{O}\right), 30.9\left(\mathrm{CH}_{3}\right), 30.7,29.5$, 29.3, 29.2, 29.2, 29.1, 29.0, 28.8, 28.7, $25.6\left(2 \times \mathrm{CH}_{2}\right), 24.6$; ESI-MS: $m / z=380.1502\left([\mathrm{M}+\mathrm{Na}]^{+}\right.$, calcd 380.1508).

$S$-(11-((2-(1H-Imidazol-4-yl)ethyl)amino)-11-oxoundecyl) ethanethioate 4 (AcS-MUDA-HA). $97 \mathrm{mg}$ AcS-MUDA (0.27 mmol, 1 equiv.) were dissolved in DMF to form a clear solution. $34 \mathrm{mg} \mathrm{HA} \cdot 2 \mathrm{HCl}$ ( $0.30 \mathrm{mmol}, 1.1$ equiv.) and a few drops $\mathrm{NEt}_{3}$ were added and the solution was stirred overnight. Subsequently $50 \mathrm{~mL}$ water were added and a white solid appeared. The precipitate was filtered off and washed three times with water. The crude product was dissolved in $\mathrm{CHCl}_{3}$, filtered again and purified via column chromatography $\left(\mathrm{CHCl}_{3} / \mathrm{MeOH} \quad 9 / 1 R_{\mathrm{f}}=0.7\right)$. After evaporation $70 \mathrm{mg}$ (0.19 mmol, 70\%) of a colorless powder were obtained.

${ }^{1} \mathrm{H}$ NMR (400 MHz, $\left.\mathrm{CDCl}_{3}\right): \delta / \mathrm{ppm}=7.50(\mathrm{~s}, 1 \mathrm{H}, \mathrm{CH}), 6.75$ (s, 1H, CH), 6.33 (br s, 1H, NH), 3.52-3.42 (m, 2H, $\mathrm{CH}_{2}(\mathrm{HA})$ ), 2.79-2.69 (m, 2H, $\mathrm{CH}_{2}(\mathrm{HA})$ ), 2.53-2.39 (m, 2H, $\mathrm{CH}_{2}$ ), 2.56 (s, $\left.3 \mathrm{H}, \mathrm{CH}_{3}\right), 2.10\left(\mathrm{t}, J=7.24 \mathrm{~Hz}, 2 \mathrm{H}, \mathrm{CH}_{2}\right), 1.59-1.43(\mathrm{~m}, 4 \mathrm{H}$, $\left.\mathrm{CH}_{2}\right), 1.26-1.14\left(\mathrm{~m}, 12 \mathrm{H}, \mathrm{CH}_{2}\right) ;{ }^{13} \mathrm{C} \mathrm{NMR}\left(100 \mathrm{MHz} \mathrm{CDCl}_{3}\right)$ : $\delta / \mathrm{ppm}=196.4\left(\mathrm{C}_{\mathrm{q}}, \mathrm{C}=\mathrm{O}\right.$, acetyl $), 173.7\left(\mathrm{C}_{\mathrm{q}}, \mathrm{C}=\mathrm{O}\right.$, amide $)$, $134.8\left(\mathrm{CH}, \mathrm{C}_{\mathrm{ar}}\right), 127.6\left(\mathrm{C}_{\mathrm{q}}, \mathrm{C}_{\mathrm{ar}}\right), 118.6\left(\mathrm{CH}, \mathrm{C}_{\mathrm{ar}}\right), 39.2$ $\left(\mathrm{CH}_{2}(\mathrm{HA})\right), 36.9\left(\mathrm{CH}_{2}\right.$ (HA)), $30.7\left(\mathrm{CH}_{3}\right), 29.5,29.3,29.3,29.2$, 29.1, 28.7, 28.4, 26.9, 25.7; ESI-MS: $m / z=354.2221\left([\mathrm{M}+\mathrm{H}]^{+}\right.$, calcd 354.2210).

\section{Animals}

Female and male Wistar rats with a body mass of 200-250 g were used. The animals were bred and housed at the institute for Veterinary Physiology and Biochemistry of the JustusLiebig-University Giessen at an ambient temperature of $22.5^{\circ} \mathrm{C}$ and air humidity of $50-55 \%$ on a $12 \mathrm{~h}: 12 \mathrm{~h}$ light-dark cycle with free access to water and food until the time of the experiment. Experiments were approved by the named animal welfare officer of the Justus Liebig University (administrative number 487_M) and performed according to the German and European animal welfare law.

\section{Solutions}

The standard solution for the Ussing chamber experiments was a buffer solution containing $\left(\mathrm{mmol} \mathrm{l}^{-1}\right)$ : $\mathrm{NaCl} 107, \mathrm{KCl}$ 4.5, $\mathrm{NaHCO}_{3}$ 25, $\mathrm{Na}_{2} \mathrm{HPO}_{4}$ 1.8, $\mathrm{NaH}_{2} \mathrm{PO}_{4}$ 0.2, $\mathrm{CaCl}_{2}$ 1.25, $\mathrm{MgSO}_{4} 1$ and glucose 12 . The solution was gassed with carbogen $\left(5 \% \mathrm{CO}_{2}\right.$ in $\left.95 \% \mathrm{O}_{2}, \mathrm{v} / \mathrm{v}\right)$; $\mathrm{pH}$ was 7.4 . For the $\mathrm{Cl}^{-}$-free buffer, $\mathrm{NaCl}$ and $\mathrm{KCl}$ were substituted by $\mathrm{Na}$ gluconate and $\mathrm{K}$ gluconate (KGluc), respectively. The $\mathrm{Ca}^{2+}$ concentration in the $\mathrm{Cl}^{-}$-free buffer was increased to $5.75 \mathrm{mmol} \mathrm{l}^{-1}$ to compensate for the $\mathrm{Ca}^{2+}$-buffering properties of gluconate. ${ }^{30}$

\section{Tissue preparation}

Animals were killed by stunning followed by exsanguination. The serosa and tunica muscularis were stripped away by hand to obtain a mucosa-submucosa preparation of the distal colon. Briefly, the colon was placed on a small plastic rod with a diameter of $5 \mathrm{~mm}$. A circular incision was made near the anal end with a blunt scalpel, and the serosa together with the tunica muscularis was gently removed in a proximal direction. Two segments of the distal colon of each rat were prepared.

\section{Short-circuit current measurements}

The mucosa-submucosa preparation was fixed in a modified Ussing chamber bathed with a volume of $3.5 \mathrm{ml}$ on each side of the mucosa. The tissue was incubated at $37^{\circ} \mathrm{C}$ and shortcircuited by a computer-controlled voltage-clamp device (Ingenieur Büro für Mess- und Datentechnik Mussler, Aachen, Germany) with correction for solution resistance. Tissue conductance $\left(G_{\mathrm{t}}\right)$ was measured every minute by the voltage deviation induced by a current pulse $( \pm 50 \mu \mathrm{A}$, duration $200 \mathrm{~ms})$ under open-circuit conditions. Short-circuit current $\left(I_{\mathrm{sc}}\right)$ was continuously recorded on a chart-recorder. $I_{\mathrm{sc}}$ is expressed as $\mu \mathrm{Eq} \mathrm{h}^{-1} \mathrm{~cm}^{-2}$, i.e. the flux of a monovalent ion per time and area, with $1 \mu \mathrm{Eq} \mathrm{h} \mathrm{h}^{-1} \mathrm{~cm}^{-2}=26.9 \mu \mathrm{A} \mathrm{cm}^{-2}$. At the end of each experiment, tissue viability was tested by administration of the cholinergic agonist, carbachol $\left(5 \times 10^{-5} \mathrm{~mol} \mathrm{l}^{-1}\right.$ at the serosal side) and/or the administration of forskolin $\left(5 \times 10^{-6} \mathrm{~mol} \mathrm{l}^{-1}\right.$ at the mucosal and the serosal side), an activator of adenylate cyclase(s), which induce a strong $\mathrm{Ca}^{2+}$-respective cAMP-dependent $\mathrm{Cl}^{-}$secretion. ${ }^{23,24}$

\section{Drugs}

Au-MUDOLS, Au-MUDA-HA, carbachol, cimetidine, histamine dihydrochloride, and mepyramine were dissolved in aqueous stock solutions. Forskolin (Calbiochem, Bad Soden, Germany) was dissolved in ethanol (final maximal concentration $0.25 \%, \mathrm{v} / \mathrm{v}$ ). Tetrodotoxin was dissolved in $2 \times 10^{-2} \mathrm{~mol}$ $\mathrm{I}^{-1}$ citrate buffer. If not indicated otherwise, drugs were from Sigma, (Taufkirchen, Germany).

\section{Statistics}

Results are given as means \pm SEM, with the number $(n)$ of investigated tissues. When means of several groups had to be compared, an analysis of variance was performed followed by post hoc Tukey's-test. For the comparison of two groups, a Mann-Whitney $U$-test was applied. $P<0.05$ was considered to be statistically significant.

\section{Acknowledgements}

We wish to acknowledge Anne Schulze (Institute of Inorganic and Analytical Chemistry, Justus-Liebig-University at Giessen) for the TEM images.

\section{References}

1 H. Goesmann and C. Feldmann, Angew. Chem., Int. Ed., 2010, 49, 1362.

2 K. Park, ACS Nano, 2013, 7, 7442.

3 R. Shenhar and V. M. Rotello, Acc. Chem. Res., 2003, 36, 549.

4 M.-C. Daniel and D. Astruc, Chem. Rev., 2004, 104, 293. 
5 S. Panigrahi, S. Basu, S. Praharaj, S. Pande, S. Jana, A. Pal, S. Ghosh and T. Pal, J. Phys. Chem. C, 2007, 111, 4596.

6 M. Mammen, S.-K. Choi and G. M. Whitesides, Angew. Chem., Int. Ed., 1998, 110, 2908.

7 C. Fasting, C. A. Schalley, M. Weber, O. Seitz, S. Hecht, B. Koksch, J. Dernedde, C. Graf, E.-W. Knapp and R. Haag, Angew. Chem., Int. Ed., 2012, 51, 10472.

8 J. E. Gestwicki, C. W. Cairo, L. E. Strong, K. A. Oetjen and L. L. Kiessling, J. Am. Chem. Soc., 2002, 124, 14922.

9 J. Dernedde, S. Enders, H.-U. Reissig, M. Roskamp, S. Schlecht and S. Yekta, Chem. Commun., 2009, 932.

10 M. Paolino, L. Mennuni, G. Giuliani, M. Anzini, M. Lanza, G. Caselli, C. Galimberti, M. C. Menziani, A. Donati and A. Cappelli, Chem. Commun., 2014, 50, 8582.

11 M.-C. Saada, J.-L. Montero, D. Vullo, A. Scozzafava, J.-Y. Winum and C. T. Supuran, J. Med. Chem., 2011, 54(5), 1170.

12 M. Böhme, M. Diener and W. Rummel, Pflügers Arch. Eur. J. Physiol., 1991, 419, 144.

13 R. Greger, Annu. Rev. Physiol., 2000, 467.

14 Y. Z. Wang and H. J. Cooke, Gasterointest. Liver Physiol., 1990, 258, 887.

15 G. Schultheiss, B. Hennig, W. Schunack, G. Prinz and M. Diener, Eur. J. Pharmacol., 2006, 546, 161.

16 A. Bell, M. Althaus and M. Diener, Pflügers. Arch. Eur. J. Physiol., 2015, 467, 1809.

17 J. Turkevich, P. C. Stevenson and J. Hillier, Discuss. Faraday Soc., 1951, 11, 55.

18 J. Wilcoxon, J. Phys. Chem. B, 2009, 113(9), 2647.
19 S.-Y. Lin, Y.-T. Tsai, C.-C. Chen, C.-M. Lin and C.-h. Chen, J. Phys. Chem. B, 2004, 108(7), 2134.

20 R. P. Briñas, M. Maetani and J. J. Barchi, J. Colloid Interface Sci., 2013, 392, 415.

21 N. Zheng, J. Fan and G. D. Stucky, J. Am. Chem. Soc., 2006, 128, 6550.

22 M. Roskamp, S. Enders, F. Pfrengle, S. Yekta, V. Dekaris, J. Dernedde, H.-U. Reissig and S. Schlecht, Org. Biomol. Chem., 2011, 9, 7448.

23 D. Strabel and M. Diener, Eur. J. Pharmacol., 1995, 274, 181.

24 R. J. Bridges, W. Rummel and B. Simon, N. S. Arch, Pharmacol., 1983, 323, 355.

25 F. Hug, M. Diener and E. Scharrer, Z. Ernahrungswiss., 1996, 35, 323.

26 J. C. Garrison and T. W. Rall, in Goodmann and Gilman's The Pharmacological Basis of Therapeutics, ed. A. G. Gilman, T. W. Rall, A. S. Nies and P. Taylor, Pergamon Press, New York, 8th edn, 1990, p. 574.

27 L. L. Brunton, in Goodmann and Gilman's The Pharmacological Basis of Therapeutics, ed. A. G. Gilman, T. W. Rall, A. S. Nies and P. Taylor, Pergamon Press, New York, 8th edn, 1990, p. 897.

28 P. Panula, P. L. Chazot, M. Cowart, R. Gutzmer, R. Leurs, W. L. S. Liu, H. Stark, R. L. Thurmond and H. L. Haas, Pharmacol. Rev., 2015, 67(3), 601.

29 C. W. Cairo, J. E. Gestwicki, M. Kanai and L. L. Kiessling, J. Am. Chem. Soc., 2002, 124, 1615.

30 J. Kenyon and W. R. Gobbins, J. Gen. Physiol., 1977, 70, 635. 